\title{
The Effect of Educational Program for High Risk People about Stroke Prevention
}

\author{
RedaAbdelSalam Ibrahim ${ }^{1}$, andFatma El-SayedSoliman ${ }^{2}$ \\ ${ }^{I}$ Medical Surgical Nursing, Faculty of Nursing, Tanta University \\ ${ }^{2}$ Communityhealth Nursing,Faculty of Nursing, Tanta University
}

\begin{abstract}
The lacks of general population knowledge aboutthe warning signs of strokes and the risk factors may increase the risk for having a stroke. For increasing awareness of the community about the disease, effective stroke prevention programs should be found to lower the incidence of strokes. More prevention and reduction of modifiable risks is needed.
\end{abstract}

Aims of the study areto assess knowledge, practice and attitude about stroke among high risk peopleand toevaluatethe effect of educational program on knowledge practice and attitude of high risk people.An Interview sheet was used to collect data for this study.

Results: the study showed that the age oftwo thirds of studied sample were more than 50 yearsold,morethan half of participants (68.3\%) were from rural area and $45 \%$ of them were illiterate. Two thirds of participants had BMI $\geq 30$. Majority of participants (80\%) were hypertensive and about two thirds (65\%) were diabetic. In relation to knowledge about definition of stroke, warning signs, risk factors and knowledge of immediate action and there were significance differences among pre, immediate and two months post program implementation.

Conclusion: The knowledge about stroke, warning signs and symptoms, risk factors,prevention of complications and immediate action were improved by the educational program for high risk people of stroke. Moreover, the attitude toward the stroke became positive.

Recommendations: Health education about strokes, warning signs and symptoms, risk factors,prevention of complications and immediate action should be introduced among high risk people in different settings.

Keywords: stroke, high risk, prevention.

\section{Introduction}

Stroke is important leading causes of mortality and morbidity worldwide and third cause of death in the United States. Additionally, it is the main cause of long-term disability,accounting for $85 \%$ of global deaths from stroke occur in developing countries. ${ }^{(1)}$ According to epidemiological studies in Egypt, incidence of stroke inLower Egypt was 91/100 000 and Upper Egypt was 1.8/1000. And the mortality after stroke in Egyptian patients was found to be 19.92 . $^{(2)}$

Stroke isa sudden episode of focal neurological dysfunction caused by obstruction or rupture of any blood vessel to the brain. Interruption of circulation leads to tissue death, as manifested by clinical signs and abnormalities on magnetic resonance imaging that are characteristic of ischemia ${ }^{(3)}$.According the extent and location of damage to brain tissue, stroke mayalso affect individuals' physical, mental,psychological and social functioning ${ }^{(4)}$.The main clinical manifestations areinability to move, aphasiaor dysphagia, vision alterations, mental changes, headache, numbness or tingling and dizziness or weakness. ${ }^{(5)}$

More than half of all strokes are preventable, understanding of individuals their personal risk factor/ factors could lead to improve controlling of modifiable risk factors and reduced incidence of stroke ${ }^{(6)}$ Although the risk factors for a stroke are preventable and/or controllable, the public awareness of these risk factors is low.Smoking,hypertension, heart disease, high cholesterollevel, obesity, sedentary lifestyle, diabetes, use of oral contraceptives,excess alcohol intake, and stress are the main modifiable risk factors for strokes . ${ }^{(7)}$

Many of these controllable risk factors of a stroke can be preventedby simple lifestyle or habits changes. These changes include measuring blood pressure, prohibiting smoking cigarettes, early detection and treating diabetes, restricting or keeping an alcohol intake at a moderatelevel, eating a healthy diet that is low in cholesterol and sodium, obtaining a regular medicalcheckups and providing a physically active lifestyle. ${ }^{(8)}$

The lacks ofgeneral population knowledgeaboutthe warning signs of strokes and the risk factors may increase the risk for having a stroke. For increasing awareness of the community about the disease,effective stroke prevention programs should be foundto lower the incidence ofstrokes. More prevention and reduction of modifiable risks is needed. ${ }^{(9,10)}$ General knowledge about stroke improves correct identification and adds to the body of essential and technical knowledge, while practices performed by people to prevent and treat stroke and attitude toward stroke is affected by their knowledge.Knowledgeboutrisk factors of stroke and warning signs,proper practicesor the immediate action is important in dealing with a stroke. As well as, theright attitude toward stroke prevention can control both mortality and morbidity among the public ${ }^{(11)}$. 
Within the scope of practice, the nursesshould educate people lifestyle and /or habit changes. The nurses' role includes emphasis on promotion of healthand disease prevention. The nurses should educatethe populationto promotetheir knowledge, attitude and practice. In addition to educatethe high risk peoplestheexternal influencing factors of patients and family and must be considered. To develop an effective education plan for the patient, the current knowledge base must firstbe determined. People who are lacking in knowledge regarding stroke signs, symptoms and risk factors are at higher risk for a stroke. ${ }^{(12.13)}$

\section{Aims of the study:}

1. Assess knowledge, practice and attitude about stroke among high risk peoples.

2. Evaluate the impact of educational program on knowledge ,practice and attitude of high risk patients.

\section{Hypotheses:}

1. The high risk people for stroke have low knowledge and improper practice regarding strokes.

2. The knowledge, attitude and practices of high risk people for stroke will improve after the educational program is performed.

\section{Research design}

\section{Subjects And Method}

quasi experimental study design was used.

\section{Settings}

The study was conducted atoutpatientMedical Clinics atTanta University Hospitals.

\section{Sampling:}

A convenient sample of persons who had one or more of the high risk factors of stroke was taken from the previously mentioned study settings. The total number was 60 patients were included in the study whowere diagnosed by one or more diseases such as diabetes mellitus, heart diseases, hypertension, obesity, kidney disease , rheumatoid arthritis, ....ect.

\section{Tool for data collection:}

An interview questionnairesheet was developed based on the related literatures and used by the researchers use to collect data for this study. It included the following parts:

1. Part one: was concerned with socio-demographicdata of studied subjects such as age, marital status, income, number of children, height, weight, body mass index, past medical history, history of previous stroke or transient ischemic attack, smoking history and family history.

2. Part two: Knowledge and practicesof studied subjects: It was used bythe researchers to assess high risk patients' knowledge regarding definition of stroke, risk factors, warning manifestations, signs, immediate interventions and preventive measures, and sources of knowledge about stroke.

3. Part three:Attitude of studied subjectsabout stroke: It was used by the researchers to assess the attitude of high risk patientstoward stroke.

The previous toolwas usedbefore preprogram implementation, immediatelypost program implementation and after two months for follow up.

\section{Scoring systems}

1. Assessment sheet for measuring weight and height and calculate the body mass index $(\mathrm{BMI})^{12}$ : normal $\mathrm{BMI}=$ $18.5-24.9 \mathrm{~kg} / \mathrm{M} 2$, overweight $\mathrm{BMI}=25.0-29.9 \mathrm{Kg} / \mathrm{M} 2$, obesity $\mathrm{BMI}=30.0-39.9 \mathrm{~kg} / \mathrm{M} 2$ and the extreme obesity $\mathrm{BMI}=40.0 \mathrm{~kg} / \mathrm{M} 2$.

2. The total scoreof knowledge, attitudes, and practiceranged from (0-150). It was graded as follows; from 0 to $50 \%$ had been gradedpoor, from $50 \%$ to less than $75 \%$ score had been graded fair and more than $75 \%$ score had been graded as good.

\section{Pilot study:}

Ethical approval of the pilot study was obtained. The pilot study was conducted on 5 patients who were excluded from the study sample. In order to test the clarity, feasibility and applicability of the study tool.Modifications and omissions of some details were done and then the final forms were developed based on the result of the pilot study. 
An official permission was obtained from directors of Tanta University Hospitals. The participant patients fulfilled the inclusion criteria were involved in this study. A complete description of the purpose and nature of the study was explained to the participants and the consent was taken from each participants.

\section{Procedures of the study:}

Data collectionswereperformed pre, immediate and post implementation of educational program from February to may 2015. The program booklet andvisual materialswere prepared by theresearchers as well as the program content. They were presented to five expertise in nursing. Based on the opinion of expertise, some modifications were performed, and then the final forms were developed then implementation of the program was carried out. The duration of each session took approximately 60 -90 minutes; sessions started according to the patient'sspare time at outpatient clinic in conference hall in medical unite. A simple Arabic language was used to be suitable for the patients' level of understanding. Methods of teaching used were real situations, lectures, group discussion and demonstration. An instructional media was used; it included data show,program booklet, brochures and audiovisual materials.

\section{Educational Program:}

Educational Program was designed by the researchers to improve the knowledge, attitude and practices of high risk patients about stroke based on the related literature. It was written in Arabic language. Knowledge about stroke included definition of stroke,risk factors, warning manifestations, signs,immediate interventions and preventive measures, and sources of knowledge about stroke. The booklet was revised by a group of five expertise in Nursing for the content validity and reliability.

\section{Results}

Table (1): showed that $41.7 \%$ of participants aged from 50-60 years and age of one quarter of participants was 60-71 years old. Half of participants were females and other half were males, more than half of participants $68.3 \%$ were from rural area and $45 \%$ of them are illiterate. In relation to marital status the study revealed that $86.7 \%$ were married and $58.3 \%$ of them didn't work. Majority of participants (90\%) didn't live alone and $60 \%$ of them reported that family income was enough.

Table (1): Frequency of socio-demographic data among studied patients.

\begin{tabular}{|c|c|c|c|}
\hline \multirow[t]{2}{*}{ Categories } & & \multicolumn{2}{|c|}{ The studiedsample $(n=60)$} \\
\hline & & \multirow{2}{*}{$\frac{\mathbf{N}}{12}$} & \multirow{2}{*}{$\begin{array}{l}\% \\
20.0\end{array}$} \\
\hline 1. Age (years) & $40-50$ years & & \\
\hline & $51-60$ years & 25 & 41.7 \\
\hline & $61-70$ years & 15 & 25.0 \\
\hline & $>70$ years & 8 & 13.3 \\
\hline & $\begin{array}{l}\text { Range } \\
\text { Mean } \pm \text { SD }\end{array}$ & \multicolumn{2}{|c|}{$\begin{array}{l}(40-85) \\
59.30 \pm 9.934\end{array}$} \\
\hline \multirow[t]{2}{*}{ 2. Gender } & male & 30 & 50.0 \\
\hline & female & 30 & 50.0 \\
\hline \multirow[t]{2}{*}{ 3. Residence } & Rural & 41 & 68.3 \\
\hline & Urban & 19 & 31.7 \\
\hline \multirow[t]{5}{*}{ 4. Educational level } & university & 3 & 5.0 \\
\hline & secondary & 12 & 20.0 \\
\hline & elementary & 3 & 5.0 \\
\hline & read \& write & 15 & 25.0 \\
\hline & illiterate & 27 & 45.0 \\
\hline \multirow[t]{2}{*}{ 5. Marital status } & married & 52 & 86.7 \\
\hline & Single & 8 & 13.3 \\
\hline \multirow[t]{3}{*}{ 6. Occupation } & works & 16 & 26.7 \\
\hline & does not work & 35 & 58.3 \\
\hline & on pension & 9 & 15.0 \\
\hline \multirow[t]{4}{*}{ 7. live alone } & No & 54 & 90.0 \\
\hline & Yes & 6 & 10.0 \\
\hline & enough & 36 & 66.7 \\
\hline & Not enough & 20 & 33.3 \\
\hline
\end{tabular}

Figure (2): The percentage of Body Mass Index in participants, the figure showed that two thirds of participants had BMI more 30. 


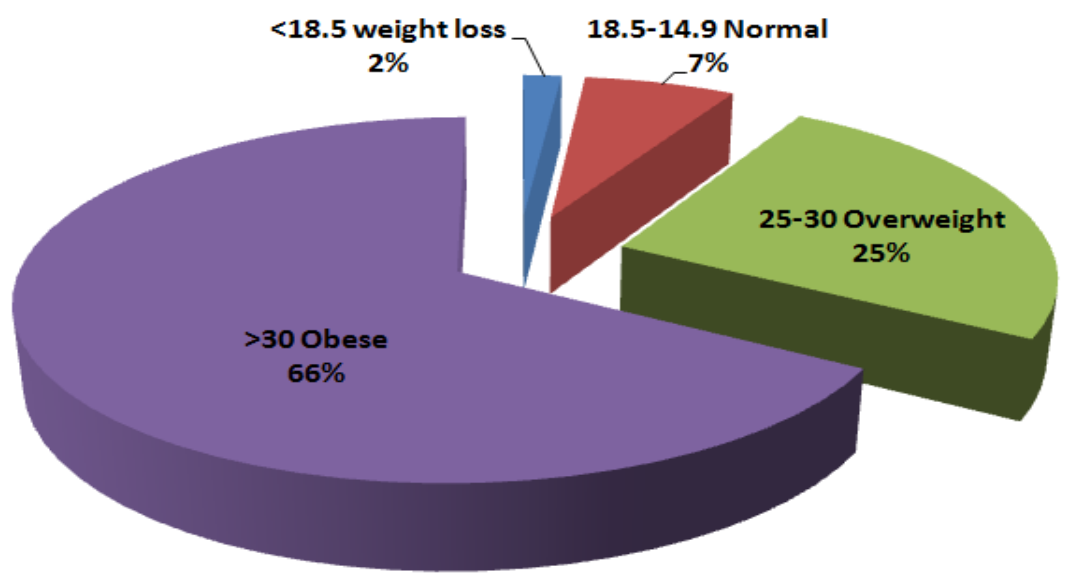

Table (3): showed Frequency of present smoking and physical activity among studied patients. The study revealed that more than half of patients $51.7 \%$ didn't smoke and $60 \%$ of them had physical activity.

Table (3): Frequency of present smoking and physical activity among studied patients.

\begin{tabular}{|l|l|l|l|}
\hline \multicolumn{2}{|l|}{ Categories } & \multicolumn{2}{|c|}{ The studiedsample(n=60) } \\
\cline { 3 - 5 } \multicolumn{2}{|c|}{} & $\mathbf{N}$ & N \\
\hline \multirow{3}{*}{$1 . \quad$ Present smoking } & No & 31 & 51.7 \\
\cline { 2 - 4 } & Yes & 20 & 33.3 \\
\cline { 2 - 4 } & Past & 9 & 15.0 \\
\hline \multirow{2}{*}{$2 . \quad$ Physical activity } & No & 24 & 40.0 \\
\cline { 2 - 4 } & Yes & 36 & 60.0 \\
\hline
\end{tabular}

Table (4):The study revealed that majority of them (80\%) were hypertensive and about two thirds $(65 \%$ and $66.7 \%)$ were diabetic and obese respectively. But only $31.7 \%$ had received anticoagulants drugs.

Table (4): Frequency of present medical history among studied patients.

\begin{tabular}{|c|c|c|c|c|}
\hline \multirow[t]{3}{*}{ Categories } & \multicolumn{4}{|c|}{ The studied sample(n=60) } \\
\hline & \multicolumn{2}{|c|}{ No } & \multicolumn{2}{|c|}{ Yes } \\
\hline & $\mathbf{N}$ & $\%$ & $\mathbf{N}$ & $\%$ \\
\hline 1. Blood pressure & 12 & 20.0 & 48 & 80.0 \\
\hline 2. $\quad$ Diabetes & 21 & 35.0 & 39 & 65.0 \\
\hline 3. Cardiac disease & 46 & 76.7 & 14 & 23.3 \\
\hline 4. fat or Cholesterol & 54 & 90.0 & 6 & 10.0 \\
\hline 5. $\quad$ obesity & 20 & 33 & 40 & 67 \\
\hline 6. arrhythmia & 52 & 86.7 & 8 & 13.3 \\
\hline 7. $\quad$ Blood diseases & 59 & 98.3 & 1 & 1.7 \\
\hline 8. $\quad$ asthma & 59 & 98.3 & 1 & 1.7 \\
\hline 9. Taking medication for blood clot & 41 & 68.3 & 19 & 31.7 \\
\hline
\end{tabular}

Table (5): Frequency of family medical history among studied patients. The study revealed that $58.3 \%$ and $51 \%$ had family history of hypertension and diabetes mellitus respectively while more than one third $(35 \%)$ of participants had family history of stroke .

Table (5): Frequency of family medical history among studied patients

\begin{tabular}{|ll|l|l|l|l|}
\hline \multirow{2}{*}{ Categories } & \multicolumn{4}{|l|}{ The studied sample(n=60) } \\
\cline { 3 - 6 } & No & Yes & \multicolumn{2}{l|}{} \\
\cline { 3 - 6 } & $\mathbf{N}$ & $\mathbf{N}$ & $\mathbf{N}$ \\
\hline 1. & Blood pressure & 25 & 41.7 & 35 & 58.3 \\
\hline 2. & Diabetes & 29 & 48.3 & 31 & 51.7 \\
\hline 3. & Cardiac disease & 55 & 91.7 & 5 & 8.3 \\
\hline 4. & fat or Cholesterol & 52 & 86.7 & 8 & 13.3 \\
\hline 5. & obesity & 48 & 80.0 & 12 & 20.0 \\
\hline 6. & arrhythmia & 58 & 96.7 & 2 & 3.3 \\
\hline 7. & osteoarthritis & 59 & 98.3 & 1 & 1.7 \\
\hline 8. & asthma & 59 & 98.3 & 1 & 1.7 \\
\hline 9. & Stroke & 39 & 65.0 & 21 & 35.0 \\
\hline
\end{tabular}

Table (6): Distribution of studied samples according to their sources of information. The study showed that more than half of participants $65 \%, 63 \%$ and $61 \%$ had information from relatives/ friends , family 
members who had stroke previously and from hospital visits respectively while $26.7 \%$ had information from newspapers and magazine .

Table (6): Distribution of studied samples according to their information sources

\begin{tabular}{|ll|l|l|l|l|}
\hline \multirow{2}{*}{ Sources } & \multicolumn{4}{l|}{ The studied sample(n=60) } \\
\cline { 3 - 6 } & \multicolumn{2}{|l|}{ No } & \multicolumn{2}{l|}{ Yes } \\
\cline { 3 - 6 } & $\mathbf{N}$ & $\mathbf{\%}$ & $\mathbf{N}$ & $\mathbf{\%}$ \\
\hline 1. & TV/Radio & 33 & 55.0 & 27 & 45.0 \\
\hline 2. & Internet & 44 & 73.3 & 16 & 26.7 \\
\hline 3. & Relatives/Friends & 21 & 35.0 & 39 & 65.0 \\
\hline 4. & Newspapers/magazines & 41 & 68.3 & 19 & 31.7 \\
\hline 5. & Family member/friends had a stroke & 22 & 36.7 & 38 & 63.3 \\
\hline 6. & Family's Doctor & 42 & 70.0 & 18 & 30.0 \\
\hline 7. & Training Programs & 29 & 48.3 & 31 & 51.7 \\
\hline 8. & Medical Books & 39 & 65.0 & 21 & 35.0 \\
\hline 9. & Community health services & 45 & 75.0 & 15 & 25.0 \\
\hline 10. & Hospital visit & 23 & 38.3 & 37 & 61.7 \\
\hline
\end{tabular}

Table (7): Means scores of knowledge domains about stroke among participants, in regarding knowledge about definition of stroke, warning signs, risk factors and knowledge of immediate action, theresults revealed that there is a significance difference among pre, immediate and two months post program implantation.

Table (7): Means scores of knowledge domains about stroke among studied samples throughout periods of study .

\begin{tabular}{|l|l|l|l|l|l|}
\hline \multirow{2}{*}{ Knowledge domains } & \multicolumn{2}{|l|}{ The studied sample $(\mathbf{n}=\mathbf{6 0})$} & \multirow{2}{*}{ F } & \multirow{3}{*}{ P } \\
\cline { 3 - 5 } & Pre & Immediate & Post 2 months & & \\
\cline { 2 - 5 } & Mean \pm SD & Mean \pm SD & Mean \pm SD & & \\
\hline 1. $\quad$ Definition of stroke & $7.47 \pm 3.624$ & $11.12 \pm 2.992$ & $11.18 \pm 2.879$ & $\mathbf{2 6 . 8 0 6}$ & $\mathbf{0 . 0 0} *$ \\
\hline 2. $\quad$ Warning signs \& symptoms & $9.27 \pm 4.765$ & $14.45 \pm 4.168$ & $14.42 \pm 4.339$ & $\mathbf{2 7 . 1 9 3}$ & $\mathbf{0 . 0 0} *$ \\
\hline 3. Signs of stroke & $18.23 \pm 8.800$ & $30.88 \pm 8.687$ & $30.55 \pm 9.644$ & $\mathbf{3 8 . 0 4 5}$ & $\mathbf{0 . 0 0} *$ \\
\hline 4. $\quad$ Risks of stroke & $20.48 \pm 11.454$ & $37.07 \pm 11.653$ & $37.85 \pm 12.122$ & $\mathbf{4 1 . 8 3 4}$ & $\mathbf{0 . 0 0} *$ \\
\hline 5. $\quad$ Action for treat stroke & $8.83 \pm 3.950$ & $11.43 \pm 3.481$ & $11.90 \pm 3.453$ & $\mathbf{1 2 . 4 0 0}$ & $\mathbf{0 . 0 0} *$ \\
\hline Total knowledge score & $1.25 \pm 0.474$ & $2.30 \pm 0.809$ & $2.38 \pm 0.783$ & $\mathbf{4 8 . 1 3 2}$ & $\mathbf{0 . 0 0} *$ \\
\hline
\end{tabular}

* Significant at $\mathrm{P}<0.05$.

Table (8) : showed perception about strokes: in relation to perception of participants about strokesare preventable disease, theyoccur only for elderly people and they are spiritual disease caused by evil there were significance difference among pre, immediate and 2 months post program implementation .

Table (8)Distribution of studied samples according to their perception about stroke

\begin{tabular}{|c|c|c|c|c|c|c|c|c|c|}
\hline \multirow[t]{3}{*}{ Believes } & & \multicolumn{6}{|c|}{ The studied sample $(n=60)$} & \multirow[t]{3}{*}{$\square^{2}$} & \multirow[t]{3}{*}{$\mathbf{P}$} \\
\hline & & \multicolumn{2}{|c|}{ Pre } & \multicolumn{2}{|c|}{ Immediate } & \multicolumn{2}{|c|}{ Post 2 months } & & \\
\hline & & $\mathbf{N}$ & $\%$ & $\mathbf{N}$ & $\%$ & $\mathbf{N}$ & $\%$ & & \\
\hline \multirow{3}{*}{$\begin{array}{l}\text { 1. Lifestyle could be } \\
\text { modified to reduce } \\
\text { the risk of stroke }\end{array}$} & Do not Know & 16 & 26.7 & 18 & 30.0 & 14 & 23.3 & \multirow[t]{3}{*}{1.203} & \multirow[t]{3}{*}{0.878} \\
\hline & Do not agree & 2 & 3.3 & 1 & 1.7 & 1 & 1.7 & & \\
\hline & Agree & 42 & 70.0 & 41 & 68.3 & 45 & 75.0 & & \\
\hline \multirow{3}{*}{$\begin{array}{l}\text { 2. Stroke is a } \\
\text { preventable disease }\end{array}$} & Do not Know & 27 & 45.0 & 14 & 23.3 & 13 & 21.7 & \multirow[t]{3}{*}{16.049} & \multirow[t]{3}{*}{$0.003 *$} \\
\hline & Do not agree & 10 & 16.7 & 4 & 6.7 & 6 & 10.0 & & \\
\hline & Agree & 23 & 38.3 & 42 & 70.0 & 41 & 68.3 & & \\
\hline \multirow{3}{*}{$\begin{array}{ll}\text { 3. Stroke requires } \\
\text { emergency treatment }\end{array}$} & Do not Know & 16 & 26.7 & 13 & 21.7 & 13 & 21.7 & \multirow[t]{3}{*}{2.001} & \multirow[t]{3}{*}{0.735} \\
\hline & Do not agree & 6 & 10.0 & 4 & 6.7 & 3 & 5.0 & & \\
\hline & Agree & 38 & 63.3 & 43 & 71.7 & 44 & 73.3 & & \\
\hline \multirow{3}{*}{$\begin{array}{l}\text { 4. Stroke is one of the } \\
\text { killer diseases }\end{array}$} & Do not Know & 19 & 31.7 & 13 & 21.7 & 17 & 28.3 & \multirow[t]{3}{*}{2.812} & \multirow[t]{3}{*}{0.590} \\
\hline & Do not agree & 3 & 5.0 & 7 & 11.7 & 5 & 8.3 & & \\
\hline & Agree & 38 & 63.3 & 40 & 66.7 & 38 & 63.3 & & \\
\hline \multirow{3}{*}{$\begin{array}{l}\text { 5. Stroke only affect the } \\
\text { elderly }\end{array}$} & Do not Know & 25 & 41.7 & 15 & 25.0 & 14 & 23.3 & \multirow[t]{3}{*}{10.038} & \multirow[t]{3}{*}{$0.04 *$} \\
\hline & Do not agree & 18 & 30.0 & 25 & 41.7 & 33 & 55.0 & & \\
\hline & Agree & 17 & 28.3 & 20 & 33.3 & 13 & 21.7 & & \\
\hline \multirow{3}{*}{$\begin{array}{l}\text { 6. Stroke is the spiritual } \\
\text { disease caused by } \\
\text { evil spirits }\end{array}$} & Do not Know & 23 & 38.3 & 16 & 26.7 & 16 & 26.7 & \multirow[t]{3}{*}{10.230} & \multirow[t]{3}{*}{ 0.037* } \\
\hline & Do not agree & 27 & 45.0 & 40 & 66.7 & 41 & 68.3 & & \\
\hline & Agree & 10 & 16.7 & 4 & 6.7 & 3 & 5.0 & & \\
\hline
\end{tabular}

* Significant at $\mathrm{P}<0.05$. 


\section{Discussion}

The primary stroke prevention for high risk peoples is a major concern for medical and nursing staff. The aim of this study is to promote the knowledge, attitudes and practices of theses peoples through providing effectiveeducational programs. The results of this study showed that two thirds of the sample were more than 50 years, half of the participants were females and other half were males. This is in line with ${ }^{(13,14)}$ they pointed that cardiovascular and metabolic disease incidence increase with age, people who more likely to experience strokes are old people. Age is the single most important risk factor for stroke. The stroke rate increase more than doubles in both men and womenfor each successive 10 years after age 55years old.Nearly three quarters of people older than 65 years are liable to stroke. Stroke incidence rates are 1.25 times greater in men, but because men tend to live shorter thanwomen, more women than men die of stroke each year.

More than half of participants $68.3 \%$ were from rural areas and $45 \%$ of them were illiterate.Aseducational opportunities are more in the urban than in the rural areas. However, Kothari et al ${ }^{[13]}$ did not find any correlation between better awareness and education. But most studies on public awareness of strokehave found that knowledge about stroke varies positively witheducation in people from developed countries ${ }^{(15,16,17,18)}$.In addition,more than half $58.3 \%$ of them didn't work, it was related to retirement after age more than 50 years.

Two thirds of participants had BMI more 30 , the obesity is important risk factor of stroke, this is agreement with ${ }^{(19)}$ who stated that abdominal obesity increases ischemic stroke risk in all ethnic groups. Individuals who are overweight or obese experience large decreases in life expectancy. In addition, obesity is also associated with hypertension, high blood glucose and elevated blood lipid levels all of which increase the risk of stroke .

More than half of patients $51.7 \%$ didn't smoke and $60 \%$ of them had physical activity, these may be due to majority of participants were from rural areas and worked farmers and half of them were female so that the Egyptian traditions and culture prohibited women's smoking and encouraged early wakeup and physical activity . This is disagreement with Gillum et al ${ }^{(20)}$ who stated that an association of physical inactivityand increase stroke risk is present in both men and women .

Majority of participants $80 \%$ were hypertensive and about two third $65 \%$ were diabetic this is in line with ${ }^{(21,22)}$ Who stated that the most common cause of stroke is high blood pressure as it strains blood vessel walls causing them to thicken and deteriorate. Studies from Asia showed ischemic and hemorrhagic strokes had the same risk factors, especially a history of hypertension being the major predisposing risk factor. ${ }^{(10) \text {. }}$

More than half of participant a $58.3 \%$, and $51 \%$ had a family history of increase blood pressure and diabetes mellitus respectively while more than one third $35 \%$ of participants had a family history of stroke, this is in line with ${ }^{(14)}$ who stated that the age, gender ,race and family / hereditary are non-modifiable risk factors of stroke Also more than half of participants had information about stroke from relatives/ friends, family members who had stroke previously and from hospital visits. This upheld the findings of study among an Australian urban population by Sug Yoon et al. ${ }^{[23]}$ who stated that among the urban population, health care providers were the next identified source of stroke information about half of sample while they ranked third of sample from radio among the rural population. The minority of individuals in previous study had heardinformation on strokefrom relatives/friends than health personnel. And there is another study mentioned thatrural population doesn't obtain effective information about strokes from health care givers. Strokesinformation from electronic media-radio are the main source that the higher proportion of participants to be obtained. Rural population may be better served by receiving information on stroke through the radio.(24)

In relation to knowledge about definition of stroke, warning signs, risk factors and knowledge of immediate action, theresults revealed that there is significance differences among pre, immediate and two months post program implantation. Multiple studies have reported that outside the western industrialized world there is inadequate knowledge of strokes ${ }^{(25)}$ in previous study, the lack of information on risk factors and warning signs for stroke was much higher than in other samples. While this knowledge gap is obvious. It also identifies multiple potential opportunities to promote general knowledge especially among people at high risk for stroke and low level of education and reduce both stroke risk factors and complications in those individuals in the future ${ }^{(26)}$. Even in developed countries like the United States There is a lack of knowledge about stroke among the public ${ }^{(25)}$ and Australia ${ }^{(11)}$ Perception and knowledge of stroke were poor in consistent with other reports, among Ugandan samples ${ }^{(25,26,)}$.

Almost $75 \%$ of participants wrongly mentioned that organ affected in stroke is the heart. The participants though that there was association of stroke with heart disease because of their local belief that the heart is a major organ of thinking. Other study revealed that low level of education and old age may lead to limited interaction with society and therefore to less interest in following revolution of medical and scientific developments, and thereby resulting in decrease the level of health care knowledge about strokes and their management .So it is very important of increasing public awareness about strokes and their prevention, particularly in the at-risk population. Initiatives promoting the retention of simple and accurate information in relation to the warning signs, symptoms, and treatment of stroke in both patients and families or care givers as 
theyengaged in stroke rehabilitation and this may be an effective ways of dissemination of this information to the general public. ${ }^{(25)}$

\section{Conclusion}

The educational program for high risk people of stroke improve their knowledge about stroke, warning signs and symptoms, risk factors, prevention of complications and immediate action, Moreover the attitude toward the stroke became positive .

\section{Recommendations}

1. Health education about stroke, warning signs and symptoms, risk factors, prevention of complications and immediate action on should be introduced among high risk people in different settings.

2. The nurses in medical unites and outpatient clinics should be trained and assume their roles in stoke prevention forhigh risk people.

3. Community based studies are required in the future including both urban and rural population to confirm the findings

4. Public awareness about stroke prevention should be maintained through mass media, booklets, brochures

\section{References}

[1]. Marques O., Silva GS., Feitosa MR., FigueiredoNL., Fiorot TN., RochaTN., MassaroAR., Leite JP., Stroke Awareness in Brazil Alarming Results in a Community-Based Studystroke.ahajournals.org.vol.65 no.3a 2007.

[2]. M.R. Kandil, H.N El-Tallawy, H.M Farawez, G. Khalifa , M. A. Ahmed, S.A. Hamed and A.M. Ali. Epidemiology of cerebrovascular Stroke and TIA in Upper Egypt (Sohag) - Relative Frequency of Stroke in Assiut University HospitalEgypt J. Neurol. Psychiat .Neurosurg. Vol. 43 (2) - July 2006.

[3]. Sarhan E., , El Serafi O., Zaki M. , The Problem of stroke in Egypt, Master (Msc) Thesis ,Cairo University ,Giza, Egypt , 2003.

[4]. Kathleen M., Marianne S., Stroke Prevention and Management in Older Adults Journal of Cardiovascular Nursing September 2006, Volume :21 Number 5 - Supplement, page S21- S26.

[5]. Nakibuuka J, Sajatovic M, Katabira E, Ddumba E, Byakika-Tusiime J, Furlan A. Knowledge and Perception of Stroke: A Population-Based Survey in Uganda . Stroke :Volume 2014 (2014), Article ID 309106, 7.

[6]. Rosamond, W., Flegal, K., Furie, K., Go, A., Greenlund, K., Haase, N., et al. (2008). Heart disease and stroke statistics-2008 update: A report from the American Heart Association Statistics Committee and Stroke Statistics Subcommittee. Circulation, 117(4), e25-e146.

[7]. Dorothy L D., Murphy S., FarrellyE..Journal of Stroke and Cerebrovascular Diseases Volume 21, Issue 8, November 2012, Pages $629-635$

[8]. Billett J., Knowledge about Stroke in Adults from Rural Ms. Theses Graduate Research and Creative Practice 2001.

[9]. Das s., Das S.,K., Knowledge, Attitude and Practice of stroke in India versus other developing and developed countries . Annals of Indian Academy of Neurology 2 013,Oct-Dec. ,16(4):488-493.

[10]. WHO. Physical status: the use and interpretation of anthropometry. Report of a WHO Expert Committee. WHO Technical Report Series 854. Geneva: World Health Organization, 1995.

[11]. Control, ed. Heart Disease and Stroke Prevention. Atlanta, Ga: Department of Health and Human Services; 2006.

[12]. Thom T, Haase N, Rosamond W, Thom T. Heart disease and stroke statistics-2006 update: a report from the American Heart Association Statistics Committee and Stroke Statistics Subcommittee. Circulation. 2006;113:e85-151.

[13]. Kothari R, Sauerbeck L, Jauch E, Broderick J, Brott T, Khoury J, et al. Patient's awareness of stroke signs, symptoms and risk factors. Stroke 1997;28:1871-5.

[14]. Pancioli AM, Broderick J, Kothari R, Brott J, Tuchfarber A, Miller R, et al. Public perception of stroke warning signs and knowledge of potential risk factors. JAMA 1998;279:1288-92.

[15]. Sug Yoon S, Sung BS, Heller RF, Levi C, Wiggers J, Fitzgerald PE. Knowledge of stroke risk factors, warning symptoms and treatment among an Australian urban population. Stroke 2001;32:1926-30.

[16]. Parahoo K, Thompson K, Cooper M, Stringer M, Ennis E, McCollam P. Stroke: Awareness of the signs, symptoms and risk factorsa population based survey. Cerebrovasc Dis 2003;16:134-40.

[17]. American Heart Association . Heart disease and stroke statistics: 2005 update, Dallas ,2005.

[18]. Gullim RF, Mussolino ME, Ingram DD. Physical activity and stroke incidence in women and men : Epidemiology follow up study , Am J Epidemiology 143:9, 1996.

[19]. PriyankaS,Kamalnayan Prevention of stroke among hypertensive patients: A recent update B, Innovational Journal of Nursing and Healthcare (IJNH), JNH Vol 1 (2), 133-138, 2015.

[20]. Kozier B, Glenora E, Audrey.b, Karen,Traditional risk factors of ischemic stroke in youngadults include smoking, diabetes mellitus and hypertension. (2005).Fundamentals of Nursing, 7th ed, Pearson'sEducation; 547-52.

[21]. S. Sug Yoon, R. F. Heller, C. Levi, and J. Wiggers, "Knowledge and perception about stroke among an Australian urban population," BMC Public Health, vol. 1, no. 1, article 14, 2001

[22]. Abbas K, Irfan A, Sheikh R, Mariam Shakir M, KazimS, Aziz F, Javed S, Aly Z, Taj F, Fatmi Z. Awareness of stroke risk factors, signs and treatment in a Pakistani population. Community Health Sciences journal of Pakistan medical association v 59 no 7 July 2009.

[23]. S. P. Jones, A. J. Jenkinson, M. J. Leathley, and C. L. Watkins, Stroke knowledge and awareness: an integrative review of the evidence, Age and Ageing, vol. 39, no. 1, pp. 11-22, 2009. View at Publisher • View at Google Scholar · View at Scopus.

[24]. O. Ayanniyi, O. Akande, and A. F. Mustapha, "Knowledge and perception of stroke among adults in Osogbo, Nigeria," African Journal of Medicine and Medical Sciences, vol. 35, no. 4, pp. 447-452, 2006.

[25]. A. Hickey, A. O'Hanlon, H. McGee et al., "Stroke awareness in the general population: knowledge of stroke risk factors and warning signs in older adults," BMC Geriatrics, vol. 9, no. 1, article 35, 2009.

[26]. Ferris A, Robertson RM, Fabunmi R, Mosca L. American Heart Association and American Stroke Association national survey of stroke risk awareness among women. Circulation 2005; 111: 1321-6. 